\title{
This Is the End: Earthquake Narratives and Buddhist Prophesies of Decline
}

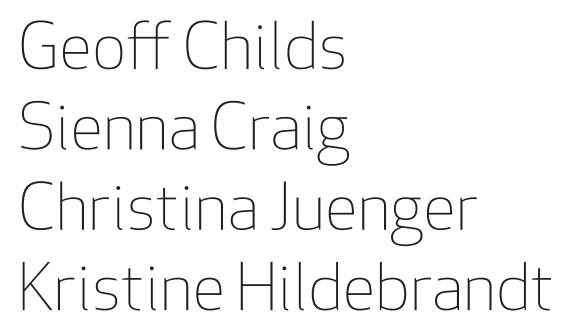

"This Is the End" presents findings from research in which the authors asked survivors of Nepal's 2015 earthquakes to describe what they know about earthquakes based on their lifelong cultural and environmental experiences, how they responded to the devastating events, and how they view these earthquakes and their aftermath in terms of cause and consequence. The research settings of Tsum, Nubri, Manang, and Mustang were in the midst of rapid socioeconomic transformations and environmental disruptions when the earthquakes struck. Interviews shortly after the event reveal that many people are familiar with scientific concepts like the movement of tectonic plates, yet they attribute the earthquake's ultimate cause to human activities that disturb autochthonous deities. Their interpretations suggest parallels with signs of impending doom contained within written prophesies, including a decline in religious devotion, the fraying of social cohesion, and environmental disruptions.
The linking of written prophesies with lived experiences points toward a Buddhist understanding of conventional and ultimate realities in which people discuss the material and geophysical causes and consequences of earthquakes while also considering moral and cosmological understandings stemming from socially and environmentally destructive behaviors. This article contributes to a growing literature on the intersections of religion and natural disasters.

Keywords: earthquake; Buddhism; prophesy; causation; Nepal 


\section{Introduction}

Özer Buti, a thirty-one-year-old woman of Trok village in Nubri, Nepal, casually spins wool while being interviewed by Jhangchuk Sangmo, also of Trok. Özer Buti looks relaxed and composed, a demeanor which contrasts with her description of the moment in spring 2015 when the earthquake struck. She was in a village further up-valley, giving fodder to her horse, when the earth shook, turning buildings into rubble all about her. She talks about navigating damaged trails to reach her home, not knowing if anything or anyone had survived, and her anxiety when unable to contact her children living in a distant boarding school. She survived the earthquakes, as did most people in Nubri. When Jhangchuk then asked why the earthquake struck, Özer Buti tentatively responded, "If it (an earthquake) comes like this, then perhaps this eon is finished."

Jhangchuk Sangmo was a member of the Narrating Disaster project, a collaborative research effort formed in the aftermath of the 2015 earthquakes to document survivors' experiences across four affected mountainous areas in central Nepal (from east to west: Tsum, Nubri, Manang, and Mustang), areas that represent diverse religious traditions, cultural practices, and languages but adhere to some basic contours of Tibetan culture. Our project asked survivors to describe what they know about earthquakes based on their lifelong cultural and environmental experiences, how they responded to the devastating events, and how they view their world through these earthquakes and their aftermath, particularly in terms of cause and consequence. Although Özer Buti's response represents just one among many, it prompts us to focus on the Tibetan notion that cataclysmic events may be interpreted as signs of moral and social decline that signal that the end of time is imminent.

The seismically active Himalayan region attracts substantial earthquake-related research. Scientists and historians have verified previous earthquakes, estimated their magnitudes, and assessed potential damages using historical accounts, archaeology, and other methods (Jackson 2002; Ambraseys and Jackson 2003; Rajendran et al. 2013; Ahmad et al. 2014). For example, Ambraseys and Jackson (2003) document several earthquakes across the Himalayan region, including one with an estimated magnitude of 8.2 in 1505 that devastated villages and monasteries from Mustang to Kyirong (Tibet)-the precise location of our current research. Jackson (2002) translated first-hand accounts by Tibetans who witnessed the earthquake and its destruction. Ramble and Drandul (2019) found a reference in the autobiography of Kunzang Longyang to a 1680 earthquake that levelled parts of Mustang. Some of the people interviewed for this project were old enough to recall the 1934 earthquake that caused substantial damage from Kathmandu to Bihar in India (Nasu 1935; Rāṇā 2013), including in highland areas like Khumbu where Tengboche Monastery was destroyed (Ortner 2001).

Beyond the voluminous scientific literature on Nepal's 2015 earthquakes, studies of earthquake hazards and risks (Bracken et al. 2018), and perspectives from anthropologists and geographers on the direct aftermath (Warner et al. 2015; Lord 2015; Shakya 2015; Craig 2016; Lord and Murton 2017; Bennike 2017; Plachta 2020; Spoon et al. 2020, 2021), few studies have explored how victims use their cultural lenses to interpret causes and consequences. Tibetan and Nepali societies are not unique in this omission. Until recently, most research on hazards and disasters excluded religion from the analysis (Gaillard and Texier 2010) or relegated religious interpretations to the realm of "superstition" that had little analytical or practical value in contemporary studies (Chester and Duncan 2010: 87). Gregersen notes that religion is often a blind spot in disaster studies (2016), while Rumahuru and Kakiay (2020) point out that disaster studies focus on political-economic factors that shape disasters and post-event responses but rarely consider theological points of view despite the role that religious knowledge plays in shaping how people interpret and respond to cataclysmic events. Chester and Duncan (2007) even claim that reactions to natural disasters published in academic journals and official reports often purge or neglect religious perspectives. They argue that such a "hidden history" of human responses has practical dimensions, for religion can help people endure disasters through psychological preparedness and by motivating them to overcome the aftereffects (Chester and Duncan 2010: 87; Gregersen 2016; Craig 2020). Recent social science scholarship that centers Indigenous knowledge and other forms of non-Western ontological approaches to conceptualizing nature, environment, and relationships between human and non/more-than-human entities (Ogden et al. 2013; de la Cadeña 2015), including a focus on climate change in the Himalayas (Sherpa 2014; Gagné 2019), gestures toward future disaster scenarios as they relate to understandings of Earth as, itself, sentient and animated by powerful forces of sacred geography. However, these examples focus less on acute disasters such as earthquakes and more on long-term and chronic impacts of human misuse of natural resources. And, although more scholars have begun to document religious interpretations of natural disasters (Chester and Duncan 2010; Merli 2010; Sørensen and Albris 2016; Gergan 2017; Gianisa and Le De 2018; Holmgaard 2019), there remains a dearth of literature on Tibetan understandings that we seek to partially fill. 


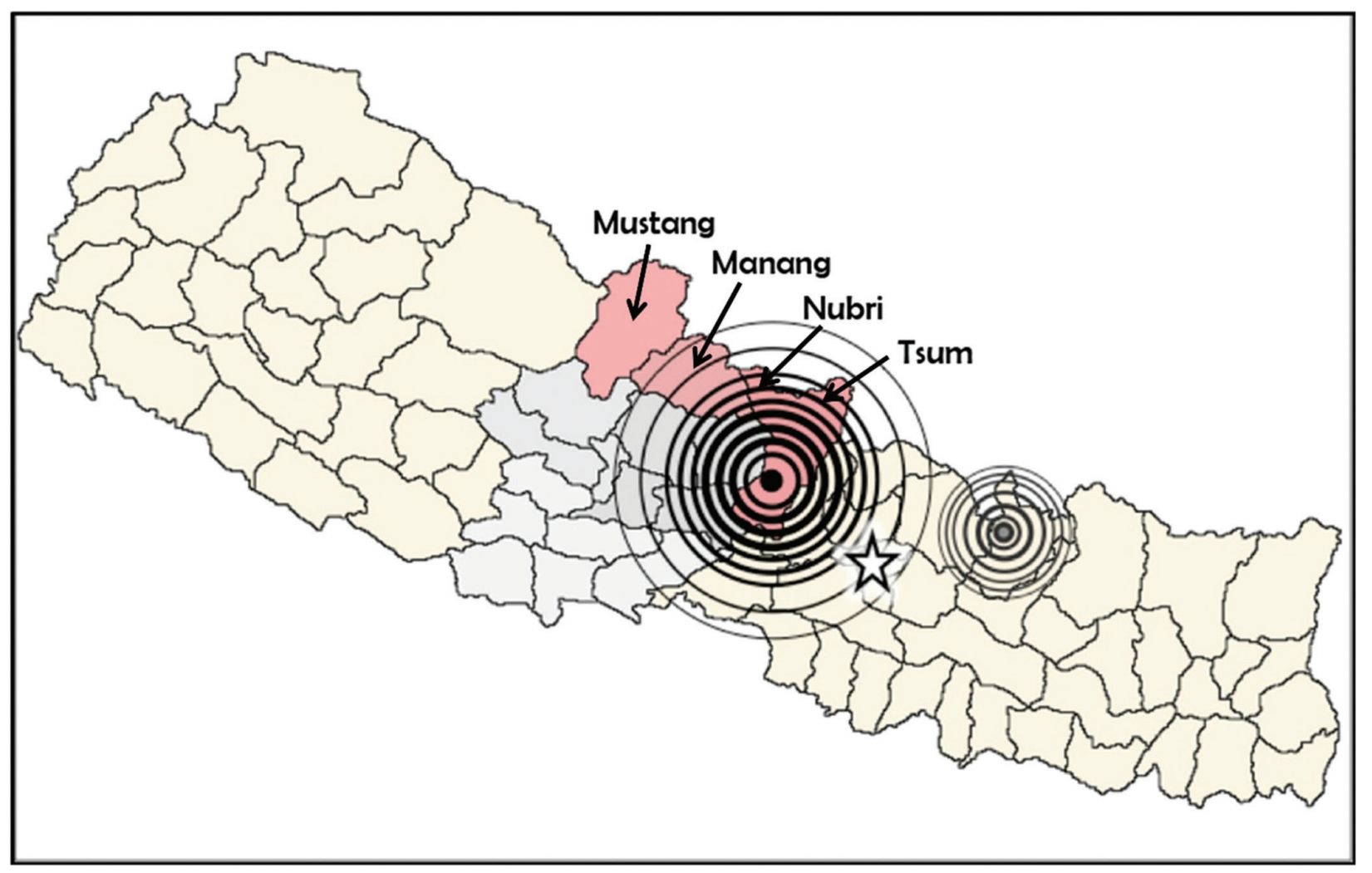

Figure 1: Map of Nepal showing fieldwork areas in relation to April $25^{\text {th }}$ (left) and May $12^{\text {th }} 2015$ earthquake epicenters. (Credit: Mark Donohue).

\section{Study Area and Project Design}

At noon on 25 April 2015, an earthquake of magnitude 7.8 struck northern Nepal. The epicenter at Barpak village in Gorkha District lies to the south of the areas where we have been conducting ethnographic and linguistic research since the 1990s. Tsum, Nubri, Manang, and Mustang are contiguous, culturally Tibetan, highland valleys (Figure 1). Although the areas vary somewhat in sectarian affiliations, most residents of these regions practice Tibetan Buddhism and therefore have a similar cultural orientation for interpreting cataclysmic events.

In response to the earthquakes, we launched a project titled Narrating Disaster. Because the project was essentially reactive (to a natural disaster) and time sensitive (the imperative to gather recollections while still fresh in people's minds, and before they were normalized into a local or regional narrative), the research design involved from the outset substantial local collaboration. All authors had been in contact with people in the quake-affected areas, so when the project began to take shape, we consulted with individuals about project feasibility as well as potential benefits and challenges. We recruited four young, educated researchers from each of the quake-affected areas, purchased and couriered equipment to Nepal, and obtained ethics clearance from our universities-all in two months from grant submission to implementation. Kristine Hildebrandt set off for Nepal in midsummer to train the community researchers. By the time she arrived, the Mustang research team had already gone to the field; the others embarked once they were sure travel conditions were no longer life-threatening. In all, the teams conducted hundreds of interviews with earthquake survivors. Interviewees ranged in age from eighteen to ninety-four; their average age of forty-eight reflects how youth outmigration has created a relatively old population (Childs et al. 2014). For more details on the methodology, ethics, and preliminary results, see Childs et al. 2018 and Hildebrandt et al. 2019. The names and roles of all team members are included as Appendix A.

Many people interviewed for this project gave what constitutes proximate and ultimate causes of the natural disaster-responses that often put 'scientific' causes and socioeconomic consequences in conversation with religious and cultural understandings of each. Whereas 
some younger people with secular education cited plate tectonics and other scientific grounds as the proximate cause, older people were more prone to reference a giant animal that lies beneath the ground and causes the earth to tremble when it moves. Such an animal was alternatively described as an ox, elephant, snake, fish, or frog, or it was referred to by participants using variants on the Tibetan term sangul (sa' 'gul where sa means earth and 'gul is the verb to move, shake, quake). The other term used for earthquake in our study area is sayom (sa yom; yom means to totter, shake, or sway). The ultimate cause, as hinted by Özer Buti in the beginning of this article, reflects a Buddhist moral framework in which social and religious degeneration can have disastrous consequences. Before discussing the narratives in more detail, the next two sections present Tibetan Buddhist perspectives on cyclical time and prophesies portending degenerative times. The purpose is to describe a cultural context underlying the moral frameworks expressed by earthquake survivors.

\section{Timetables for the End of Buddhism}

Buddhist cosmology divides time into eons, called kalpa (bskal pa). During a kalpa the world system forms, develops, matures, decays, and is eventually destroyed, thereby initiating a new cycle. At the beginning of a kalpa, the human life span measures thousands of years but declines to a mere ten years as abundance and comfort are supplanted by strife, pestilence, and starvation (Nattier 1991: 15-19). During Śākyamuni's time, the Buddha of the current era, it is believed that the human life span was already down to 100 years and waning. A calamity like an earthquake can be interpreted as a sign that a kalpa is coming to an end, an event associated with a decline in religious devotion and other factors that affect the ability for the Buddha's teachings to perpetuate. In our project, several people speculated that the earthquake signaled the end of an eon. For example, Pasang Chödrub from Tsum stated, "In my opinion the kalpa is coming to an end. The time is not good." Mingmar Tsering from Nar in Manang bluntly declared, "Everyone knows that the kalpa is coming to an end."

By the second century AD, Buddhist literature includes stories foretelling the demise of the Dharma, an occurrence connected to the end of a kalpa. A well-known version is the Kauśāmbī story, named after the city of a Buddhist king who inadvertently brings about the destruction of his religion. The narrative details a combination of internal and external causes for the passing of Buddhism, the internal ones being the deterioration of monastic discipline and rise of sectarian rivalries, whereas the external causes are foreign invasions by Greeks, Sakas, and Parthians, and excessive burdens imposed on Buddhist institutions by covetous rulers (Nattier 1991:119-129). The Tibetan version of the story, titled "The Prophesy of the Way the Buddha's Teachings Will Endure and Be Destroyed" from the Ārya-Candragarbha-pariprccchā-Sūtra, was translated into Tibetan from Sanskrit no later than 1,000AD (Nattier 1991:228-277). Thus, the story has been known by segments of the Tibetan population for a millennium. ${ }^{1}$

In the Kauśāmbī story, the bodhisattva Candragarbha asks the Buddha how the Dharma will disappear. He describes a 2,000-year timetable, divided into four periods of 500 years with each subsequent period bringing further religious and social decay. During the first period Buddhist practice will be strong and many people will attain liberation. The second period will also be fortuitous as many people engage in meditation. A weakening of people's devotion commences in the third period, along with a rise in warfare. During the first 300 years of the fourth and final period, deities who protect the religion will flee elsewhere in disgust. A shrunken number of devotees will fail to practice diligently while famine and disease afflict the populace. In the final 200 years, monks will abandon the teachings and turn to secular pursuits, while rulers seize monastic properties and destroy religious structures. Thus, will the Dharma come to an end (Nattier 1991: 52-53).

Elements of the Kauśāmbī story and its timetable are discernible in the prophetic literature of Padmasambhava (a.k.a. Guru Rinpoche) who is closely associated with the Nyingmapa School, a religious tradition that is strongly embedded in the valleys where we conducted research for the Narrating Disaster project. Padmasambhava's life story and teachings are prominent in Tibetan literature as well as the sacred geography and rituals of these regions in highland Nepal. His legendary efforts to promote the Dharma are quite literally inscribed onto the landscapes; natural features are interpreted as places where, for example, he meditated with his consort (Figure 2) and tamed a demoness (Figure 3). Importantly, some of Padmasambhava's prophesies, presented below, show distinct parallels with earthquake survivor's narratives, suggesting that they helped shaped interpretations of the catastrophic event.

\section{The Prophesies of Padmasambhava}

With the revival of Buddhism in Tibet during the $11^{\text {th }}$ and $12^{\text {th }}$ centuries, Padmasambhava's role in establishing the religion during the imperial period became magnified 


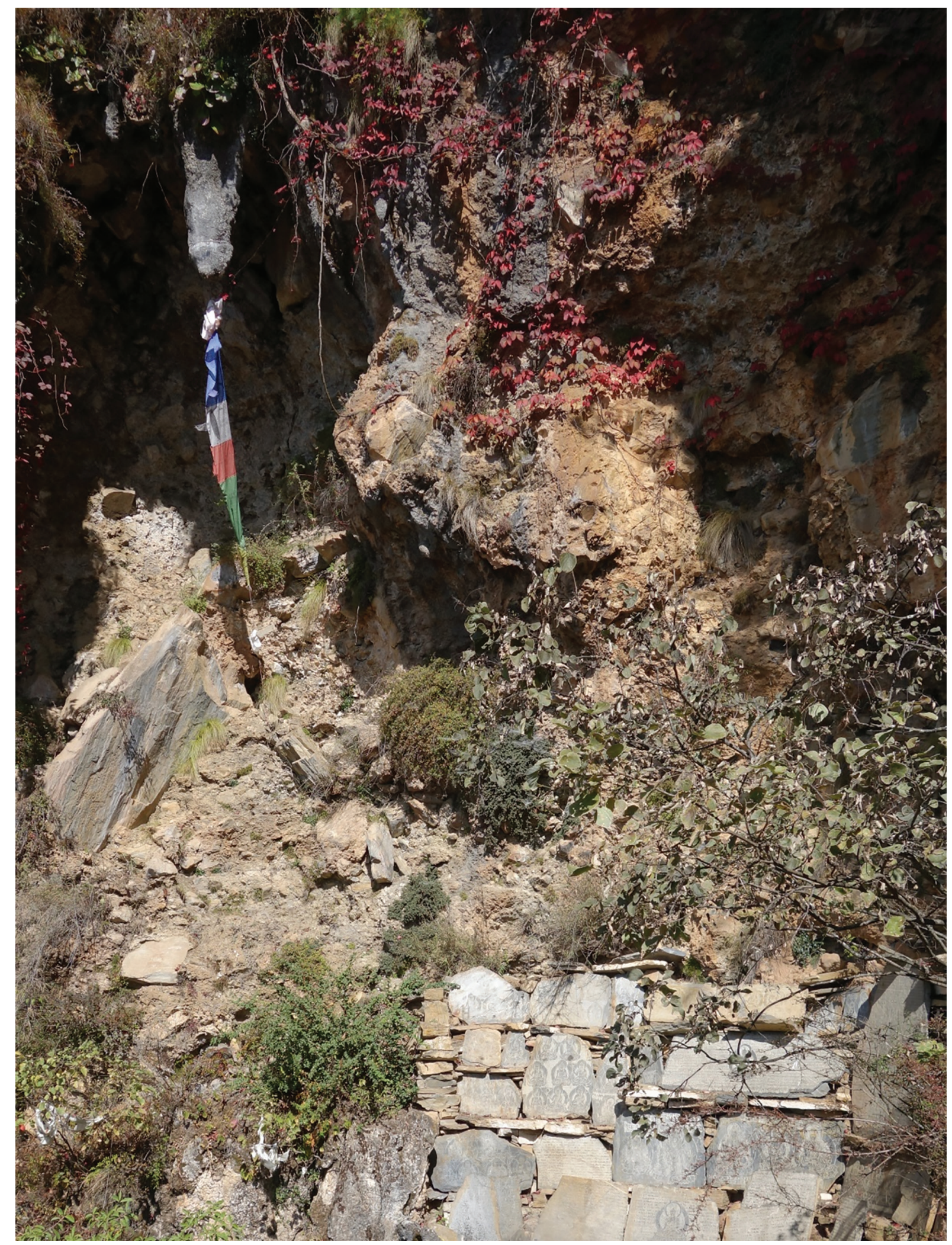

Figure 2: Self-arisen Secret Cave of Guru Rinpoche (Padsambhava) in Nubri. (Credit: Geoff Childs) 


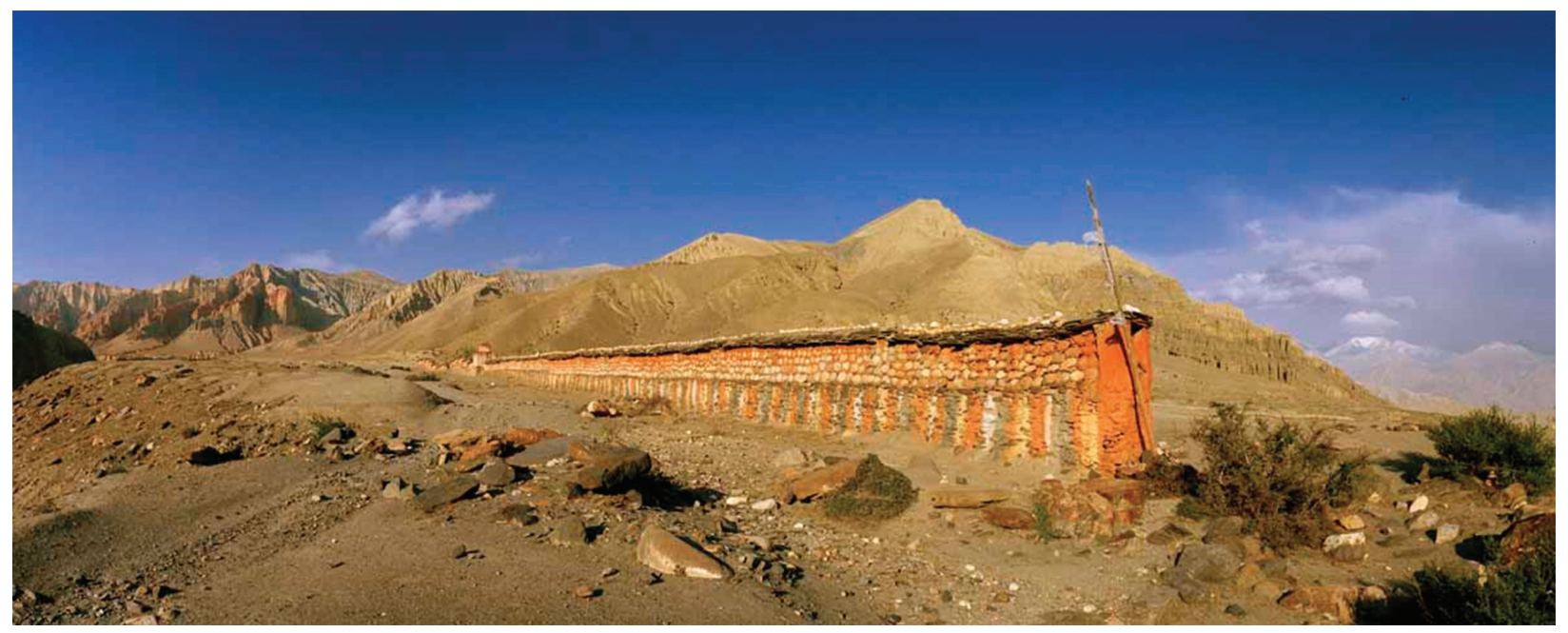

Figure 3: Maldang Ringmo, one of the longest walls of mani stones in Nepal, located between the villages of Ghami and Drakmar. This wall of carved prayers is also considered to be the intestines of the demoness that Guru Rinpoche defeated in his quest to transmit Buddhism to the Himalaya. The gray cliff beyond is her liver and the red cliffs in the distance are said to be her blood. (Credit: Macduff Everton)

through the purported discoveries of texts related to him. These included the first hagiography of Padmasambhava, The Copper Island Chronicle (Bka' thang zangs gling $\mathrm{ma}$ ) revealed by Nyangrel Nyima Ozer (1124 or 1136-1192 or 1204, see Hirshberg n.d.; Doney 2014). The twenty-first chapter of this work involves a conversation between Padmasambhava and the emperor Trison Detsen in which the former foretells a time when his hidden treasures will be discovered and used to thwart a precipitous decline of the religion. Mongol incursions during the $13^{\text {th }}$ and $14^{\text {th }}$ century prompted a fresh round of prophesies forecasting the decline of Buddhism. For example, the Five Chronicles (Bka' thang sde lnga) discovered by Orgyan Lingpa (b. 1323) contains a section titled "how the end of time will come."

Prophetic literature typically includes a description of immorality and chaos, signs that the end of the world is near, and a way to escape impending doom by returning to virtuous religious practice (Sárközi 1992: 13-15). Tibetan prophesies associated with Padmasambhava do not necessarily foretell the demise of Buddhism, but rather a steep decline that can be remedied through the discovery of hidden treasures (gter ma) and hidden lands (sbas yul). The former are teachings concealed by Padmasambhava, the latter mountain refuges where practitioners can recreate a harmonious and pious society. Much of the hidden land guides are attributed to the discoveries of Rigdzin Gödemchen Ngodrub Gyaltsen (1337-1409), a prominent figure in the Changter branch of the Nyingmapa sect
(Boord n.d.). To quote Gentry who has studied prophetic literature:

The theme of communal threat is so prevalent throughout the Treasure prophesies that we might regard this body of literature, and Treasure traditions more broadly, as particularly Tibetan strategies for gaining some purchase over the wild unpredictability of their surrounding material world of humanity and nature. (2014: 61)

Padmasambhava's prophesies resemble the Kauśāmbī story in several ways. For one, they are framed as a question-and-answer session between a master (in this case Padmasambhava) and a disciple (usually King Trisongdetsen). Like Śākyamuni's description of a blissful present in the Kauśāmbī story, Padmasambhava's opening statement is often something along the lines of, "Currently, the time period and eon are excellent. Due to the blessings of the emperor and his sons, translators and learned scholars, the sun shines on the holy doctrine. In the future there will be a bad time for the subjects of Tibet ..." (Orgyan lung bstan: $2 \mathrm{r}-2 \mathrm{v})$. $^{3}$ Furthermore, Padmasambhava's prophesies portend destructive invasions with Mongols, Turks, and Chinese replacing Greeks, Sakas, and Parthians as antagonists. The military assaults coincide with the deterioration of religious practices, benevolent governance, and social cohesion.

Padmasambhava's prophesies also indicate that the predicted events will occur near the end of a kalpa. In the Kauśāmbī story, Śākyamuni describes progressively 
worsening 500-year periods until the entire assemblage of Buddhist practitioners meets a tragic end. Mentions of 500-year spans are also common in Padmasambhava's prophesies, for example when he instructs King Trisongdetsen,

In the future during the final 500 (years), a time will come when the four border armies tremble forth and suppress the realm of Tibet. That will signal the time has come for virtuous holders of my teaching lineage and descendants of the Dharma protecting king to seek Padmasambhava's place of accomplishment. (skyid mo lung lam yig: $3 \mathrm{v})^{4}$

References to "the final 500 years" (Inga brgya tha ma la) occur in most guides to hidden lands, including one to Khenbalung where Orifino interprets the term to mean "the last five hundred years of the spread of the Doctrine" (1991: 257), which is certainly implied given the timetables discussed above. Another example is when Padmasambhava asserts that the time to search for the hidden land Yolmo Gangra "is during the final 500 (years) when the life span is nearing 50" (Yol mo gnad byang: $3 \mathrm{r}$ ). ${ }^{5}$ The declining kalpa is also signaled by a diminishing life span, so Padmasambhava's prophecies generally indicate that the time to search for hidden teachings and sanctuaries is when longevity is plummeting. For example, "Currently, happiness prevails in Tibet. But when people lose their teeth at age sixty, a bad time will arise with alternating periods of happiness and suffering. When the duration of life approaches fifty, nine demon brothers will be in Tibet" (Ga'u bdun: 1r). ${ }^{6}$

The end of the eon is also signaled by religious degradation, political turmoil, moral degeneration, and natural disasters. ${ }^{7}$ For example,

Those who do not understand the authentic instructions of the Buddha will become envious rivals of those who practice in accordance with the Dharma. Those who act contrary to the sacred Dharma will become thorns to those who practice unimpaired meditation. The great meditators who cause no harm will abandon the mountain retreats and wander about the villages. Those who claim to be fully ordained monks will desire to kill animals. Those who claim to maintain monastic discipline will condemn the teachings of Padmasambhava. They will proclaim their own school of thought to be the best. (Orgyan lung bstan: $3 r-3 v)^{8}$
Other passages reference the decline of morality and social cohesion among the laity. For example, "The people will eat flesh and blood without shame, the women who have no children will couple promiscuously, the people will be careless of their lives and struggle to acquire food and wealth with minds filled with vanity and falsity" (Orofino 1991: 257); "Fathers will fight with their sons. Masters will fight with their disciples. The king will fight with his ministers. People will be unable to trust each other; they will poison and do evil things to each other" ('Bras ljongs lam yig: 4v).

The roster of natural disasters and omens signaling the end of time includes earthquakes, floods, inauspicious celestial alignments, unseasonable weather, and famines. For example,

As for the outer signs, evil planets and bright stars will appear repeatedly in the sky. When it is time to harvest [the crops] will not be ripe. Much rain will fall in the upper and lower parts of the valley. Earthquakes will strike again and again. The glacial waters of Tise (Mt. Kailash) will be spoiled. (Padma tshal gnas yig: $7 r)^{10}$

We present these prophesies to illustrate how Tibetan Buddhists envision the end of an eon, especially those who are associated with the Nyingmapa school. Many of the texts referenced above are found in the research areas. Sbas yul skyid mo lung gi lam yig is a guide to a hidden land that encompasses Nubri and Tsum. Orgyan chen po'i ma 'ongs lung bstan prophesizes the treasure revealing activities of Garwang Dorje (1640-1685), who was born just to the north of present day Nubri and was very active in the region (Solmsdorf 2014). Copies of Bka' thang sde lnga and 'Gu ru'i ga'u bdun ma, which contains prophesies on the future discovery of teachings, are possessed by many religious practitioners throughout the research areas. They are traditional loose-leaf books (dpe cha), kept mostly in village temples but also in the homes of some householder lamas (sngags pa). They are recited on occasion, for example during rituals to commence construction activities or for household protection. In that sense, they involve a mix of oral and literary forms of knowledge transmission to younger generations of religious officiants. More 'common' knowledge about the existence of these prophesies circulates through oral tradition. These texts are known locally by learned lamas and, to a lesser extent, lay people, and therefore are likely to have some influence on shaping how people interpret natural disasters and other disruptive events. 


\section{This Is the End}

Karma Lhundrub, age fifty-three of Nyamdok, Mustang, sits outside on a grassy knoll beside his whitewashed home, built of rammed earth brick and crowned with brambles. This ex-monk and father of two is talking with Yangjin Bista, one of the researchers on the Mustang team, herself from the nearby village of Chosher. After describing where he was when the earthquake hit and what his immediate thoughts were, he turns to questions of cause and consequence.

Now we have almost reached the end of time, the end of the good era, so all of these things are happening. ... In scripture, Guru Rinpoche [Padmasambhava] said during this era he will protect all sentient beings. But now people are betraying the environment (khor yug). There is mass consumption of firewood, stones and soil. We are shaking these materials, but some of these things are where protector deities live, and some are where demons reside. Those areas which belong to such deities are being destroyed. When this happens, even the lamas and other gurus cannot do anything to solve this or protect us. When this happens, it means that a degenerate time (dus nyams) is arising.

Karma Lhundrub's thoughts show how some people link the earthquake to similar visions of degenerating times as found in the prophesy literature. But, he also refers to human actions that harm the environment and offend protector deities which hints at a more complex view, that an earthquake has both proximate and ultimate causes, which we explore below.

As noted earlier, while some younger individuals with secular education cited scientific understandings-discussions of plate tectonics and vernacular descriptions of geomorphology-as the earthquake's proximate cause, many older people and even some younger ones also mentioned the trembling of an animal dwelling beneath the earth. In one of the most detailed examples Dorje Thakuri, age sixty-one and a practitioner of traditional Tibetan medicine from Trok in Nubri explained,

When I was young, the very old people would tell us that there is an elephant under the earth... If the elephant shakes its left ear, then the earth will quake a bit strongly above where that ear is located. Elsewhere the earth will only quake a bit or in some places not at all. If it shakes its right ear, then the earth will quake a bit strongly above where that ear is located and less so elsewhere. At the end of an eon (bskal pa dus tshod mtha' ma la) if the elephant shakes its entire body, then the entire earth will quake. We refer to an eon as a kalpa, and a degenerate time as dü nyemba (dus nyams pa). ${ }^{11}$ When the degenerate time is upon us the elephant shakes its entire body. The earth quakes and many people die. It is a sign that the degenerate time has arrived, the eon is coming to an end.

For the ultimate cause, or what induced the animal to shake, like Karma Lhundrub many interviewees surmised it is triggered by negative human actions affecting the environment. In Mustang, which has recently witnessed a surge in road building and other construction efforts, several people linked the natural disaster to people offending autochthonous deities that dwell in the ground and water such as sadag (sa bdag) and lü (klu, Skt. naga). For example, forty-five-year-old Dolma Gurung of Thingkar, Mustang said, "It is a sign of the bad era because people are working more with stone and mud. The sadag and lü must be angry." Lhamo Chödron, age fifty-five of Phuwa, Mustang stated, "It might be the lü. All peoples are playing with stone and land. It is the sign the good eon is finishing. Nowadays here in the village people are using bulldozers for moving and changing the earth. We can see water and stone under the land." Phu Sangmo, age fifty-one of Ghiling explained,

Nowadays all the land is being dug out for roadways, pulling of rocks and stones out from underneath the land, so I think [the earthquake] is due to the decrease of deities (lha) and naga (liu). Also before people did not know about yartsa gunbu, but nowadays, many people are pulling this from the earth and taking with it all the wealth or luck (g.yang). ${ }^{12}$ I think in this way about the cause of the earthquake. I don't know what else might be the other causes of the earthquake.

Lü and sadag are two among an array of deities embedded in the natural surroundings that can be helpful or harmful depending on how they are treated (Samuel 1993: 161-165). Tibetans disturb the earth with caution (Tashi and Stuart 1998: 34), and usually take proactive measures when initiating construction projects by appeasing lü through a soil ritual (sa chog) before breaking ground (Gardner 2006). If one encroaches on or damages a lü's inhabitance it can retaliate by causing illness, injury, or natural disasters (Luodanduojie 2013). For example, a monk in Nubri was badly burned when something exploded inside a fire he was tending. A lama, through divination, determined that a lü occupying a tree on the monastery's grounds 
had been disturbed recently, and concluded that this must have happened when the monk helped tear down a wall surrounding the tree to build a new one. So, they performed a lü purification ritual (klu bsang) to rectify matters (Sangmo 2019). ${ }^{13}$

A chain of causation linking environmental damages that disturb lü and sadag to the earthquake seems to be quite distinct from Padmasambhava's prophesies which center more on religious decline, political turmoil, and moral degeneration. However, other testaments point to a merging of interpretive frameworks. For example, several interviewees spoke about how declining religiosity exacerbates earth-harming practices. Tsewang Tenzin, age sixty-five of Kimaling, Mustang, stated,

Now people are busy altering the stone and earth so the lü must be angry. Before in our area we did not see modern technology like tractors and [bull] dozers. In the past, there were not so many rongba [lowland Nepali] laborers. If we needed stones, first monks would perform purification rituals and if people couldn't have a monk do these rituals then they burned incense before collecting the stones. But now nobody is concerned about such practices so all gods and the sadag must be angry. And then this massive thing [the earthquake] is happening.

Another example of this view was expressed by Sangmo Gurung, age forty-seven of Ghiling, who said,

Now people are hoeing and working with more stone and mud so it must be pap [Nep. sinful]. Our people are always being sinful. In winter they are collecting firewood the whole time, and upturning earth and mud the whole summer and collecting stones [for new buildings] so the sadag must be angry and it [the earthquake] happened. If today, our people get together for mani (reciting mantras) they can do some mani today. But from tomorrow, they will forget the benefits of mani due to envy over money and business. Also, when we gather together for mani we can do some good act together, but in our own houses we don't do mani much anymore because we are always busy with work.

Note how all three referenced an increase in activities associated with a modernizing economy that, in the past, would have been smaller in scale and their impacts on deities mitigated through interventions. For Karma Lhundrub, it is not a decline in religiosity but the sheer magnitude of destruction that has exceeded lamas' abilities to rectify the situation, whereas Tsewang Tenzin and
Sangmo Gurung both see fault in a declining attentiveness to appease lü and sadag through ritual. Another person who cited both economic activities and social decay is Tsering Wangdu, a sixty-six-year-old monk living in Rö, Nubri. He became quite animated when asked about the earthquake and said,

These days we are plowing the earth, digging up stones, and extracting yartsa gunbu, so it will not turn out good. For three or four years, people will get good food. And we did get good food recently [bought using income from yartsa gunbu]. But if it continues for three, four, five, six years, then not a single house will be left. There will be nothing but shit.

When the interviewer probed, "From a religious perspective, what could cause the earthquake? What is the main cause (rgyu mtshan gtso bo)?" Tsering Wangdu replied,

The kalpa is degenerating (nyams)... Blessings (byin brlabs) are on the wane. It will continue to get worse and worse. People don't know anything, but they continue to do more and more. Nobody listens to each other. Nobody cares about religious teachings. In the sacred books it is told that things will not be good. The lamas are telling us that the kalpa is degenerating. We live in a degenerate time. When it is a degenerate time there is trouble throughout the world, not just here... Our religion and laypeople are degenerating. Our way of life is filthy (tshe stangs btsog pa). The earthquake struck because our way of life and way of making a living ('tsho stangs) are incompatible.

This social dimension of causality was emphasized by other interviewees, such as seventy-three-year-old Kunsang Namgyal of Namdru, Nubri, who reported,

Before [the earthquake] people in the village did as they wished. They only did bad deeds. There were conflicts, people dominated each other, treated each other badly. Because of this [the earthquake] might have happened. Earthquakes happen because people do bad things which causes conflicts with the sadag. People fall ill and there are famines if the deities are unsatisfied. The sadag and lü become angry.

Tsewang Tenzin, age sixty-six of Kimaling, Mustang, made a similar observation when asked about the causes of the earthquakes, 
It must be a bad omen I think. The sky is its own place and earth is also its own place, but only human beings are changing from time to time. Nowadays there is not a sense of community welfare or feelings of unity like in the past. Now people are quarreling with each other too much and making more enemies. This must be causing obstacles (bar chad).

Gyatso Gurung, age thirty-nine and of the same village said, "These days people carry envy (phrag dog), animosity (zhe sdang), carry an inner anger that hinders them (khog rlung), and have intense dissatisfaction with their lives (nar gyas). This must be due to it being a degenerate time." According to Dolkar Gurung of Ghiling, age seventy-four, "Time is not like before. People have changed their manner and behavior. There is one local saying, 'Time does not change. Human beings change. In this era, people do not have good fortune."'14

The perceived connection between human actions, social discord, and natural disasters has parallels elsewhere in the region. In Langtang, Nepal, which was devastated by an avalanche caused by the 2015 earthquake, survivors contemplated the role that greed and neglect of cultural traditions played in the disaster. According to Tenji Lama who spoke in Kesang Tsetan's film Trembling Mountain,

With the coming of tourism, we began to do well. We were much better off than everyone around us. However, whether it is because of our own deeds, karmic law, in three or four minutes our villages were destroyed. Whether it is because of our actions, we must have committed many ill-deeds. We did everything to make money. We must have cheated tourists one way or another. While doing business, we competed, slandered each other. When we made money, we desired to make even more. There was jealousy and disrespect even within our own families. We must have neglected our gods. The discord among humans must have further displeased our gods.

Many Lepchas in Sikkim link earthquakes with social causes that are internal to their communities, for example the failure to appease autochthonous deities and tensions between Buddhist and shamanic practices (Gergan 2017). They also attribute causation to economic forces that they have little control over but that offend deities by polluting the environment, such as dam building in sensitive mountain regions (ibid). Some herders in Tibet, although not referencing an acute moment of catastrophe like the Nepal earthquakes, dispute official narratives that overgrazing and pika (Ochotona curzoniae) infestations cause grassland degradation, reasons used by the state to move herders into permanent settlements and conduct mass poisoning campaigns against pikas. Instead, they attribute grassland degradation to the removal of material substances from the earth through mining and yartsa gunbu harvesting. These practices are thought to deplete the soil's vital essence (bcud) and cause offense to sadag and other deities, and to attract pikas in abundance which are considered hungry ghosts (yi dwags) (Yeh and Gaerrang 2020). These examples, alongside testimonials from earthquake survivors in our research areas, attest to a regional viewpoint that certain human activities, especially those causing offense to autochthonous deities, can have catastrophic consequences. They support Yeh and Gaerrang's point that 'Tibetan analytics' are "forms of reason that cannot be reduced to "cultural belief" (2020). What scientists often refer to as 'natural disasters' are seen by many residents of the Himalayan region as being inextricably linked to both nature and culture.

Despite large numbers of casualties throughout Nepal, very few people lost their lives in our research areas, in great measure because the earthquake struck on a Saturday when schools were closed, and around noon when most people were outdoors working in the fields. Also, houses in several of the fieldwork areas are constructed with piled stones held together by a wooden frame. Most walls collapsed outward, thereby sparing people inside from serious injury. Some people used a Buddhist explanatory framework to understand why things were not worse. A few respondents from Mustang noted that Hindu and Christian communities were more directly affected by the earthquake, which may indicate a sentiment of 'Buddhist exceptionalism,' the idea that one religious orientation can be more effective at moderating the impacts of a catastrophe than others. ${ }^{15}$ We found hints of this elsewhere. For example, when asked why there was little loss of life in Tsum, thirty-eight-year-old Sherab Chönzom attributed the low casualty rate to people's devotion to Buddhism. She said, "It is mainly because this is a place of lamas and religious teachings. Many people lost their lives in other villages, but none were killed in our village. I think it is because of our religious devotion, and blessings by the lamas." A recent history of issuing sealing decrees (sha rgya) and proclaiming Tsum to be especially blessed because it lies within the boundaries of the hidden land Kyimolung (Plachta 2018) may have shaped Sherab Chönzom's opinion that strong Buddhist traditions spared lives. Similarly, when asked whether the earthquake may signal the end of an eon, sixty-one-year-old Dorje Thakuri of Nubri referred to the decline in the human lifespan as 
described in prophesies and then observed that humans are still living relatively long lives, in some cases up to 100 years. He then stated,

Right now, things are somewhat okay. We are not at the end of an eon. There are many religious practitioners. Some engage in solitary meditation retreats (tshams), others stay in cave hermitages. The lamas initiate monks into the monasteries where they conduct religious ceremonies. People congregate for rituals, and when people die, we perform merit-making ceremonies (dge ba). This is because we live in [the sbas yul] Kyimolung. Due to the blessings (byin rlabs) of Guru Rinpoche this is a place of religious practice.

The narratives of morality and religious practice in relation to the earthquake are not uniform. Nevertheless, our corpus does present several distinct strands of argument that, as described above, tie these natural disasters to the contemporary behavior of human beings and changes in their relationship with each other and the environment. They also articulate a recuperative and somewhat hopeful narrative, tied to these regions' connections to Tibetan Buddhist history and practice. In the earthquake's aftermath, many people reported an increase in religious activities, both at a personal and communal level. In some cases, village temples served as makeshift shelters for some families whose homes were in need of repair; in cases where these temples themselves were damaged, villagers worked collaboratively to orchestrate structural repairs. In other instances, villagers organized healing or protective rituals (sku rim) for the entire community which took place in local temples. ${ }^{16}$ Some people reported elevating their own religious practices while others helped invigorate community-based rituals. Their actions suggest both individual and collective responses to rectify human shortcomings through devotional activities, a phenomenon documented elsewhere in the aftermath of catastrophes (Sibley and Bulbulia 2012; Belloc et al. 2016).

\section{Conclusions}

Social scientists have paid very little scholarly attention to the intersections of religion and contemporary disasters (Gaillard and Texier 2010: 81), in part because indigenous explanations of causality are often brushed aside as historical relics of "superstition" that can contribute little to disaster research (Chester and Duncan 2010: 87). Social scientists prefer to analyze recent catastrophic events through a lens of racial and socioeconomic inequalities and the politics of disaster relief (Stirrat 2006;
Fjord and Manderson 2009; Attinà 2012; Reddy 2018), or "the conditions of inequality and subordination in the society rather than the accidental geophysical features of the place" (Oliver-Smith 2009: 13). Such analyses often exclude voices from local communities (Harris 2012) or place more emphasis on external forces than internal community dynamics. According to Campbell, "The voices of people who have most directly been impacted by the destructive powers of an earthquake are the least likely to be heard, given the noise of outsider's organizations, agendas, and projects that arrive into the circumstances of aftermath" (2018: 109). Our objective in this article aligns with Gregersen's point that religion is often a blind spot in disaster studies, and that disaster researchers would benefit by focusing more on religious communities and their interpretive frameworks (2016: 34; see also Chester and Duncan 2007; Rumahuru and Kakiay 2020).

The Himalayan regions where we conducted Narrating Disaster were in the midst of rapid socioeconomic transformations and environmental disruptions prior to the 2015 earthquakes. Road construction was scarring the landscape and threatening the territorial integrity of religious monuments (Lotyo 2013). Pervasive outmigration for education and employment generated cultural reorientations and the unraveling of social bonds that have held communities together for centuries (Murton 2018; Childs and Choedup 2019; Craig 2020). Our research reveals that many people attribute the earthquake's ultimate cause to human economic activities that disturb autochthonous deities. It also underscores distinct parallels between explanations of earthquake causation and signs of impending doom contained within written prophesies. These include a decline in religious devotion and a corresponding increase in non-virtuous activities, the fraying of social cohesion, and environmental disruptions. Even before the earthquakes struck, we heard many people, especially the elderly, grumble when speaking of contemporary trends that they were living through a degenerate time (dus nyams). Perhaps it is no coincidence that they, who are the most disoriented by contemporary circumstances and have the most exposure to textual prophesies, are likely to interpret the earthquake as a sign that the end of an eon is near.

This article's engagement with prophesy narratives and the lived experiences of disaster point toward the relationship between what, in Buddhist framings, can be described as conventional and ultimate realities, putting them into conversation with each other. While the corpus includes many people discussing the material and geophysical causes and consequences of earthquakes, such 
as the movement of tectonic plates and the destruction of property, these explanations are not viewed as contradictory or mutually exclusive with their discussions of more 'ultimate' moral and cosmological understandings of cause and consequence of this same natural disaster. In other words, these events can be seen as both existing outside of the control of human beings and also connected to human behavior-toward the environment, including the use of natural resources (e.g. soil, stone, yartsa gunbu) and in relation to how people comport themselves and treat each other (e.g. jealousy, greed, decline of religious practice). These Himalayan communities, through their lived experiences and discourses about the earthquakes, provide a powerful example of being able to hold to both scientific and religious understandings of the changing nature of the planet without becoming dogmatically entrenched in one side or the other of this epistemological (or, in so many cases, political) divide. Education and attendant out-migration have increased understandings of earth science, including the human causes of climate change, particularly among younger generations (Craig 2020). But, migration and educational exposure to other knowledge systems has not erased understandings that cosmo-spiritual forces manifest in ways that are at once religious and geological; as Yeh and Gaerrang argue, these multiple and simultaneous viewpoints need not be contradictory and are not reducible to 'culture' (2020). In these and many other ways, there is a lot to learn from this Tibetan/Himalayan capacity to hold ideological complexity and to think with care about the dynamic processes that define life on this animate earth.
Geoff Childs, Professor of Anthropology at Washington University in St. Louis, is an anthropological demographer who studies the interplay of culture, fertility, migration, and aging. He is a former president of the Association for Nepal and Himalayan Studies and a regular collaborator on interdisciplinary projects. His most recent book, co-authored with Namgyal Choedup, is From a Trickle to a Torrent: Education, Migration, and Social Change in a Himalayan Valley of Nepal (2019, University of California Press).

Sienna R. Craig, Professor of Anthropology at Dartmouth College, is a medical and cultural anthropologist. She enjoys writing across genres, from ethnography to fiction and poetry, she is the author of The Ends of Kinship: Connecting Himalayan Lives between Nepal and New York (2020), Mustang in Black and White (2018), Healing Elements: Social Ecologies of Tibetan Medicine (2012), and Horses Like Lightning: A Story of Passage through the Himalayas (2008), among other publications. From 2012 to 2017, she coedited HIMALAYA with Mark Turin.

Christina Juenger recently graduated from Southern Illinois University Edwardsville with a Bachelor of Science in Anthropology and minors in Geographic Information Systems and Native American Studies. She currently works as a geospatial analyst in St. Louis, Missouri.

Kristine Hildebrandt is a professor in the English Department at Southern Illinois University Edwardsville. She is also the co-director of the IRIS Center for the Digital Humanities at SIUE. A documentary linguist by training, Hildebrandt has been a PI on three grants from the National Science Foundation, including one CAREER grant (Documenting the Languages of Manang, Nepal for Local and International Impact) and one RAPID grant (Narrating Disaster: Calibrating Causality and Responses to the 2015 Earthquakes in Nepal).

Funding was provided by the National Science Foundation: NSF BCS 1547377, PI Kristine Hildebrandt. Project Webpage found at: https://iris.siue.edu/nepal-earthquakes/ The authors would like to acknowledge the phenomenal contributions of the sixteen community researchers who conducted the interviews in the aftermath of the earthquake: Nyima Samdrup, Lhakpa Norbu, Lhakpa Hritar Lama, and Jangchuk Sangmo of Nubri; Namgyal Ngodup Lama, Pema Norbu Lama, Tenzin Gyeltsen, and Tenzin Kunchok of Tsum; Tsewang Gyurme Gurung, Nawang Tsering Gurung, Karma Chodron Gurung, and Yangjin Bista of Mustang; Sange Chhimi Lama, Anjana Ghale, Tsering Topden Gurung and Sophiya Lama of Manang. In addition, we acknowledge the indispensable work of Bhojraj Gautam and Dubi Nanda Dhakal, also members of the Tribhuvan University-Center for Nepal and Asian Studies linguistics team, and genla Tsetan Chonjore for generously helping with the Tibetan translations. 


\section{Endnotes}

1. A fragment of this text is contained within the Tibetan corpus of manuscripts found in a cave near Dunhuang during Sir Aurel Stein's second Central Asian expedition from 1906-1908 (La Vallée Poussin 1962: 185). Another example of prophetic literature that became known in Tibet during the imperial period is the Prophesy of Khotan (li yul lung bstan pa), although that narrative centers more on the building of Buddhist institutions in Khotan than on the decline of Buddhism (Emmerick 1967). An early parallel to the Kauśāmbī story is found in a non-Buddhist text uncovered in Dunhuang. Written in Old Tibetan it is titled The Narrative of the Fall of Mankind. Originally translated by Thomas in 1957 (45-51), it describes a favorable time when the gods are kind and humans flourish followed by a degenerate period, termed the Age of Debts and Taxes, characterized by moral depravity, social decay, warfare, and foreign invasions. In a recent examination of the text Schaeffer points out that The Narrative of the Fall of Mankind does not necessarily represent a pre-Buddhist, autochthonous Tibetan worldview because it is impossible to rule out influences from Central Asia where similar ideas prevailed at the time (2013: 127-128). Nevertheless, similar to the Kausaambī story and the Buddhist notion of cyclical kalpa, The Narrative of the Fall of Mankind portrays a cosmological viewpoint in which time oscillates between good and bad periods, swings that are associated with human morality. See also Ages of Decline, another Dunhuang text containing a religious perspective on time (Thomas 1957: 54-102).

\section{2. mtha' ma'i dus su ji ltar 'byung tshul/}

3. da lta dus dang bskal pa bzang zhing/mnga' bdag yab sras dang lo tsha' [rtsa'] la sogs mkhas grub lo pan rnams kyi bka' drin la dam pa chos kyi nyi ma shar/ ma 'ong ['ongs] pa'i dus su bod 'bangs rnams sdug pa'i dus byung zhing...

4. ma 'ongs lnga brgya'i tha ma la/ mtha'i dmag bzhi g.yos nas kyang/ bod khams 'joms pa'i dus byung tshe/ dge byed nga'i brgyud 'dzin dang/ chos skyong rgyal po'i gdung brgyud kyis/ padma'i bsgrug [sgrub] gnas tshol du 'ong/

5. yul de btshal ['tshal] ran pa'i dus ni/ Inga brgya'i tha ma la tshe tshad lnga bcu la nye ba'i dus su [so]/

6. da lta bod na bde skyid ldan/drug cu [bcu] kha ral dus ngan 'char/ bde dang sdug bsngal spel mar 'byung/ tshe tshad lnga bcu sleb khar [kha] ru/bod du 'gong po spun dgu yod/Two terms are used to reference declining longevity. The first, kha ral, means to lose one's teeth which is a sign that one is old and nearing death. The other is tshe tshad which literally means duration of life, or lifespan. Other examples include, "Then, when the human life span is between forty and thirty, because the end of the kalpa is gradually approaching ..." (Orgyan lung bstan: 3r); de nas tshe lo bzhi bcu sum bcu'i bar/rim gyi [gyis] bskal pa dus mthar 'gyur ba yis/ "In general, the essence of the Buddha's teachings will be exhausted. The teachings of Śākyamuni will become a mere reflection. This will happen when people lose their teeth between age fifty and forty" (Padma tshal gnas yig: 5r); spyir ni sangs rgyas kyi bstan pa'i snying po rdzogs/ shakya thub ba'i bstan pa'i gzugs brnyan tsam la spyod/snyings ma Inga'i yang snyings du gyur/ tshe lo lnga bcu dang bzhi bcu kha ral slebs nas song/

7. Similarly, the biography of Jamyang Rinchen Gyaltsen of Mustang asserts that he predicted a future invasion by Turks or Mongols, an earthquake, behavioral changes among people, and climate changes prior to the devastating earthquake of 1505 (Jackson 2002: 151-152).

8. sangs rgyas bka' lung tshad mar mi 'dzin par/ chos bzhin sgrub la 'gran sems phrad [phrag] dog byes [byas]/ rang nyid dam pa'i chos dang mi mthung [mthun] par/ gnod med bsam gtan sgom pa'i tsher ma byed/sgom chen ri khrod bor nas grong yul 'grim/ dge slong yin zer sems can gsod la brngam/ 'dul ba byed zer padma'i chos la smod/ rang rang lugs kyi grub mtha' kha 'dzin che/ Other examples include the following: "The great offerings to the tsuglhakhangs of Lhasa, Samye, the border taming and beyond the border taming temples will diminish and they will fall into ruins" (skyid mo lung lam yig: 13v); lha sa dang bsam yas dang mtha' 'dul dang yang 'dul kyi [gyi] gtsug lag khang phal che'i [cher] mchod pa chag cing gogs 'gro/ "The tsuglhakhang will become a tavern. Great obstacles will arise for religious practitioners... The Buddha's teachings will fragment" (Ga'u bdun: 1v-2r); gtsug lag khang la dem [dam] khang byed/ chos spyod rnams la bar chad che/...sangs rgyas bstan pa zhig tu cha/ "Monks who lack moral precepts will return to their homes. Tantric practitioners who lack sacred commitments will wander around like bonpos" (Yol mo gnad byang: 3r); tshul khrims med pa'i btsun pa grong du rgyu [rgyug]/dom [dam] tshig med pa'i sngags pa bon bzhin 'khyams/ "Religious practitioners will become consultants of the village leaders. Nuns will kill their own sons" ("Bras ljongs lam yig: $4 \mathrm{v}-5 \mathrm{r}$ ); chos pa rnams sde dpon gyi gros dpon byed/ rtsun ma rnams rang gi bu gsod/"Signs that the Buddha's teachings are in decline are that the Dharma will disperse to the less civilized borderlands. The Dharma will be perverted by attachments and aversions. Except for one or two people, everyone will accuse rather than debate. Putting aside practice they will pursue wealth. Lamas in name and form only will fill the realm" (Padma gling pa lung bstan: 1r); sangs rgyas bstan pa dman pa'i rtags/ chos rnams mtha' "khob yul du dar/chos dang chags sdang 'chol nyog spyod/gang zag re re ma gtogs pa'i/ chos can dus kyi rtsod pa bzlogs/ nyams len bzhag nas nor chog byed/ming gzugs bla mas rgyal khams khengs/

9. pha dang bu thab/slon dpon dang slob ma thab/ rje blon thab/ slog tad [blo gtad] mi thub dug dang bsam ngan byed/ 
10. phyi'i rtags ni/gnams [gnam] la gza' ngan dang/skar ma 'od chen yang yang 'char/sa la lo tog dus su mi smin char gshong sgang shod che/ sa g.yos yang yang 'byung/ti se'i gangs chu nyams/ Other examples include the following: "The celestial order, disrupted, loosens plague, famine and war to terrorize terrestrial life... No rain falls in season, but it falls out of season; the valleys are flooded. Famine, frost and hail govern many unproductive years... Earthquakes bring sudden floods while fire, storm and tornadoes destroy temples, stupas and cities in an instant" (Dowman 1973: 54); "Seasons will be unstable so rainwater will diminish. The crops will not ripen so it will be impossible to plow. Leprosy will wipe away peoples' obstacles. Epilepsy will fill the realm. All women will be possessed by demons. The nourishment contained within food will diminish. People will suffer from poverty." (Padma gling pa lung bstan: 1r); nam zla mi rtag char chu nyams/ "bras bu mi smin srid mi rmo/ mi rnams bar chad mdze yis "khyer/ltag 'gyel nad kyis rgyal khams gang/ mo skyes thams cad gson 'drer 'gyur/shing thog bcud med kha zas nyams/ mi la nor med sdug bsngal byed/

11. The degenerate time at the end of an eon resembles the Hindu concept of kaliyuga, a Sanskrit term describing an age of darkness and strife. However, Eltschinger argues that Buddhists never fully appropriated this Hindu concept because they had their own vision of decline that focused more on the demise of Buddhism than the end of the world. Nevertheless, the kaliyuga concept does appear in several Buddhist texts, reaching an apex of appropriation in the Kālacakratantra. As Eltschinger reasons, "I am inclined to assume that the appeal of the kaliyuga to the Buddhist literati became increasingly strong in the specific context of apocalyptic prophecies" (2020: 126).

12. Yartsa gunbu (Ophiocordyceps sinensis) is a caterpillarfungus complex valued for its medicinal properties. In the research areas it is dug from high pastures and has become a very important trade commodity that has led to increasing wealth and, in some areas, strife (Childs and Choedup 2014; Dolpo 2015).

13. Buddhism has coexisted for centuries with a belief in autochthonous deities despite apparent ontological differences. As Samuel has argued, a reason why Buddhism may have succeeded in becoming so well integrated with village-level beliefs was its "promise of effective protection against the spirits active in the environment, thus taking over from the older spirit practices and providing new and more impressive techniques" (2007: 222, see also 1993). Such deities are even part of disease etiology in Tibetan medical texts like the Four Medical Tantras (Rgyud bzhi) which mentions many ailments that result from disturbing a klu's domain by polluting water sources, cutting down certain trees, and excavating the earth (Samuel 2007: 214-215; see also Kocurek 2013). Even the act of hunting creatures which dwell beneath the soil, like marmots, is believed to bring misfortune to perpetrators because of the animals' close connection with lü (Huber 2004: 8).

14. Dus rnams mi 'gyur mi nrnam 'gyur/deng sang mi la bsod nams byang thang med/

15. Conversely, many Lepchas in Sikkim attribute recent earthquake activity to the gradual abandonment of indigenous deities as Buddhism gains more prominence in their communities (Gergan 2017).

16. Buddhist monasteries in Nepal played significant roles in providing relief supplies to affected villages (Schorr and Warner 2015) and sheltering people displaced by the earthquake (Lord 2015). Most religious institutions in Nubri and Tsum are small-scale village temples that were damaged by the earthquake and thus unsafe for habitation by those needing shelter.

\section{References}

Ahmad, Bashir, Hamid Sanab, and Akhtar Alam. 2014. "Macroseismic Intensity Assessment of 1885 Baramulla Earthquake of Northwestern Kashmir Himalaya, Using the Environmental Seismic Intensity Scale (ESI 2007)." Quaternary International 321: 59-64.

Ambraseys, Nicholas and David Jackson. 2003. "A Note on Early Earthquakes in Northern India and Southern Tibet." Current Science 84(4): 570-582.

Attinà, Fulvio ed. 2012. The Politics and Policies of Relief, Aid, and Reconstruction: Contrasting Approaches to Disasters and Emergencies. New York: Palgrave Macmillan.

Belloc, Marianna, Francesco Drago, and Roberto Galbiati. 2016. "Earthquakes, Religion, and Transition to SelfGovernment in Italian Cities.” The Quarterly Journal of Economics 131(4): 1875-1926.

Bennike, Rune Bolding. 2017. "Aftershock: Reflections on the Politics of Reconstruction in Northern Gorkha." HIMALAYA 37(2): 55-64.

Boord, Martin. n.d. "The First Dorje Drak Rigdzin, Rigdzin Godemchen Ngodrub Gyeltsen.” Treasury of Lives, accessed 17 September 2019, http://treasuryoflives. org/biographies/view/Rigdzin-Godemchen-NgodrubGyeltsen/7767.

Bracken, Louise, Hanna A. Ruszczyck, and Tom Robinson. 2018. Evolving Narratives of Hazard and Risk: The Gorkha Earthquake, Nepal. Palgrave Macmillan. 
de la Cadeña, Marisol. 2015. Earth Beings: Ecologies of Practice across Andean Worlds. Durham, NC: Duke University Press.

Campbell, Ben. 2018. "Communities in the Aftermath of Nepal's Earthquake." In Evolving Narratives of Hazard and Risk: The Gorkha Earthquake, Nepal, 2015, edited by Louise Bracken, Hanna Ruszczyck, and Tom Robinson, 109-123. Palgrave Macmillan.

Chester, David K. and Angus M. Duncan. 2007.

"Geomythology, Theodicy and the Continuing Relevance of Religious Worldviews on Responses to Volcanic Eruptions." In Living under the Shadow, edited by John Grattan and Robin Torrance, 203-224. Walnut Creek: Left Coast Press.

- 2010. "Responding to Disasters within the Christian Tradition, with References to Volcanic Eruptions and Earthquakes." Religion 40: 85-95.

Childs, Geoff and Namgyal Choedup. 2014. "Indigenous Management Strategies and Socioeconomic Impacts of Yartsa Gunbu (Ophiocordyceps sinensis) Harvesting in Nubri and Tsum, Nepal." HIMALAYA 34(1): 8-22.

-2019. From a Trickle to a Torrent: Education, Migration, and Social Change in a Himalayan Valley of Nepal. Berkeley: University of California Press.

Childs, Geoff, Sienna Craig, Cynthia M. Beall and Buddha Basnyat. 2014. "Depopulating the Himalayan Highlands: Education and Outmigration from Ethnically Tibetan Communities of Nepal." Mountain Research and Development 34(2): 85-94.

Childs, Geoff, Sienna Craig, Dubi Nanda Dhakal, Mark Donohue, and Kristine Hildebrandt. 2018. "Narrating Disaster through Participatory Research Perspectives from Post-Earthquake Nepal." Collaborative Anthropologies 10(1-2): 207-236.

Craig, Sienna. 2016. "Shattered Homes and Hard Choices in Post-Quake Nepal.” Sapiens https://www.sapiens.org/ culture/nepal-earthquakes/

2020. The Ends of Kinship: Connecting Himalayan Lives between Nepal and New York. Seattle: University of Washington Press.

Dolpo, Tashi Tsering Ghale. 2015. “Justice Denied to the IPs: An Analysis of Violence in Dolpo.” Journal of Indigenous Nationalities 14(6): 144-169.

Doney, Lewis. 2014. The Zangs Gling Ma: The First Padmasambhava Biography. Andiast: International Institute for Tibetan and Buddhist Studies.
Dowman, Keith (trans.) 1973. The Legend of the Great Stupa. Berkeley: Dharma Publishing.

Eltschinger, Vincent. 2020. "On Some Buddhist Uses of the Kaliyuga." In Cultures of Eschatology, Volume 1: Empires and Scriptural Authorities in Medieval Christian, Islamic and Buddhist Communities, edited by Veronica Wieser, Vincent Eltschinger, and Johann Heiss, 123-162. Oldenbourg: De Gruyter.

Emmerick, R. E. 1967. Tibetan Texts Concerning Khotan. London: Oxford University Press.

Fjord, Lakshmi, and Lenore Manderson. 2009.

"Anthropological Perspectives on Disasters and Disability: An Introduction." Human Organization 68(1): 64-72.

Gagné, Karine. 2019. Caring for Glaciers: Land, Animals, and Humanity in the Himalayas. Seattle: University of Washington Press.

Gaillard, J.C., and Pauline Texier. 2010. "Religions, Natural Hazards, and Disasters: An Introduction.” Religion 40: 81-84.

Gardner, Alexander. 2006. "The Sa Chog: Violence and Veneration in a Tibetan Soil Ritual." Études Mongoles et Sibériennes, Centrasiatiques et Tibétaines 36-37: 283-323.

Gentry, James Duncan. 2014. "Substance and Sense: Objects of Power in the Life, Writings, and Legacy of the Tibetan Ritual Master Sog bzlog pa Blo gros rgyal mtshan." PhD dissertation, Harvard University.

Gergan, Mabel Denzin. 2017. "Living with Earthquakes and Angry Deities at the Himalayan Borderlands." Annals of the American Association of Geographers 107(2): 490-498.

Gianisa, Adisaputri, and Loic Le De. 2018. "The Role of Religious Belief and Practices in Disaster: The Case Study of the 2009 Earthquake in Padang City, Indonesia." Disaster Prevention and Management 27(1): 74-86.

Gregersen, Niels H. 2016. "Theology and Disaster Studies: From “Acts of God' to Divine Presence.” In Disaster Research: Multidisciplinary and International Perspectives, edited by Rasmus Dahlberg, Olivier Rubin, and Morten Thanning Vendelø, 34-48. London: Routledge.

Harris, David. 2012. "The Impact of Cultural and Religious Influences during Natural Disasters (Volcano Eruptions)." Earthquake Report website, 27 September. Accessed 12 November 2019. https://earthquake-report. com/2012/09/27/the-impact-of-cultural-and-religiousinfluences-during-natural-disasters-volcano-eruptions/ 
Hildebrandt, Kristine, Tanner Burge-Beckley, and Jacob Sebok. 2019. "Language Documentation in the Aftermath of the 2015 Nepal Earthquakes: A Guide to Two Archives and a Web Exhibit." Language Documentation \& Conservation 13, 618-651. http://hdl.handle.net/10125/24914

Hirshberg, Daniel. n.d. Nyangrel Nyima Wozer. Treasury of Lives, accessed 21 October 2019, http://treasuryoflives.org/ biographies/view/Nyangrel-Nyima-Ozer/5999.

Holmgaard, Sanne B. 2019. "The Role of Religion in Local Perceptions of Disasters: The Case of Post-tsunami Religious and Social Change in Samoa." Environmental Hazards 18(4): 311-325.

Huber, Toni. 2004. "Antelope Hunting in Northern Tibet: Cultural Adaptations to Wildlife Behavior." In Wildlife and Plants in Tradition and Modern Tibet: Conceptions, Exploitation, and Conservation, edited by Alessandro Boesi and Francesca Cardi, 5-17. Milano: Memoire della Societa Italiana di Scienze Naturali, Milano.

Jackson, David. 2002. “The Great Western Himalayan Earthquake of 1505: A Rupture in the Central Himalayan Gap?" In Tibet, Past and Present, edited by H. Blezer, 147-160. Leiden: Brill.

Kocurek, Jakub. 2013. “Tree Beings in Tibet: Contemporary Popular Concepts of klu and gnyan as a Result of Ecological Change." Journal of Ethnology and Folkloristics 1: 19-30.

La Vallée Poussin, L. de. 1962. Catalogue of the Tibetan Manuscripts from Tun-huang in the India Office Library. London.

Lord, Austin. 2015. “Langtang. From the Series Aftershocked: Reflections on the 2015 Earthquakes in Nepal." Accessed 13 June 2021. https://culanth.org/ fieldsights/langtang.

Lord, Austin, and Galen Murton. 2017. "Becoming Rasuwa Relief: Practices of Multiple Engagement in PostEarthquake Nepal." Himalaya 37(2): 87-102.

Lotyo, Sonam. 2013. "Road to Nowhere." Nepali Times July 5-11 \#663.

Luodanduojie (Loten Dorje). 2013. "Klu in Tibet: Beliefs and Practices.” Master's thesis, University of Oslo.

Merli, C. 2010. "Context-bound Islamic Theodicies: The Tsunami as Supernatural Retribution vs. Natural Catastrophe in Southern Thailand." Religion 40(2): 104-111.

Murton, Galen. 2018. "Nobody Stops and Stays Anymore: Motor Roads, Uneven Mobilities, and Conceptualizing Borderland Modernity in Highland Nepal." In Routledge Handbook of Asian Borderlands, edited by Alexander
Horstmann, Martin Saxer, and Alessandro Rippa, 315-324. Routledge.

Nasu, Nobuji. 1935. The Great Indian Earthquake of January 15, 1934. Bulletin of the Earthquake Research Institute. 13(2): 417-432.

Nattier, Jan. 1991. Once Upon a Future Time: Studies in a Buddhist Prophesy of Decline. Berkeley: Asian Humanities Press.

Ogden, Laura, Billy Hall, Kimiko Tanika, 2013. “Animals, Plants, People, and Things: A Review of Multispecies Ethnography." Environment and Society: Advances in Research 4: 5-24.

Oliver-Smith, Anthony. 2009. "Anthropology and the Political Economy of Disasters." In The Political Economy of Hazards and Disasters, edited by Eric Jones and Arthur Murphy, 11-28. Lanham: AltaMira Press.

Orofino, Giacomella. 1991. "The Tibetan Myth of the Hidden Valley in the Visionary Geography of Nepal." East and West 41(1): 239-271.

Ortner, Sherry B. 2001. Life and Death on Mt. Everest: Sherpas and Himalayan Mountaineering. Princeton: Princeton University Press.

Plachta, Nadine. 2018. "Himalayan Borderland Communities: Identity, Belonging, and Place among the Tsumpas." PhD dissertation, Faculty of Humanities, University of Bern.

- 2020. "Narrating Disaster: The Complexities of Citizenship and Belonging in Times of Crisis." Studies in Nepali History and Society 25(1): 143-173.

Rajendran, C. P., Kusala Rajendran, Jaishri Sanwal, and Mike Sandiford. 2013. "Archeological and Historical Database on the Medieval Earthquakes of the Central Himalaya: Ambiguities and Inferences." Seismological Research Letters 84(6): 1098-1108.

Ramble, Charles, in collaboration with Nyima Drandul. 2019. Tibetan Sources for a Social History of Mustang, Nepal. Vol. 3: The Archives of Kun bzang chos gling Convent. Andiast: International Institute for Tibetan and Buddhist Studies.

Rāṇā, Brahmaśamśera Jañgabahādūra. 2013 [1935] transl. Kesar Lal. The Great Earthquake in Nepal (1934 A.D.). Kathmandu: Ratna Pustak Bhandar.

Reddy, Sunita (ed.). 2018. The Asian Tsunami and PostDisaster Aid. Singapore: Springer Nature. 
Rumahuru, Yance Zadrak and Agusthina Ch. Kakiay. 2020. "Rethinking Disaster Theology: Combining Protestant Theology with Local Knowledge and Modern Science in Disaster Response." Open Theology 6(1): 623-635.

Samuel, Geoffrey. 1993. Civilized Shamans: Buddhism in Tibetan Societies. Washington D.C.: Smithsonian Institution.

_.2007. "Spirit Causation and Illness in Tibetan Medicine." In Soundings in Tibetan Medicine: Anthropological and Historical Perspectives, edited by Mona Schrempf, 213-224. Leiden: Brill.

Sangmo, Tsewang. 2019. "Diagnostic Dilemmas: Navigating between Traditional and Modern Interpretations of Illness and Injury in Nubri, Nepal." SIT Tibetan Studies Independent Study Project.

Sárközi, Alice. 1992. Political Prophesies in Mongolia in the 17-20th Centuries. Wiesbaden: Otto Harrasowitz.

Schaeffer, Kurtis R. 2013. "The Narrative of the Fall of Mankind." In Sources of Tibetan Tradition, edited by Kurtis Schaeffer, Matthew Kapstein, and Gray Tuttle, 127-130. New York: Columbia University Press.

Schorr, Sarah, and Cameron David Warner. 2015. "The Photographed Gift: Participation, Relief Efforts, and Social Media. From the series Aftershocked: Reflections on the 2015 Earthquakes in Nepal." Accessed 13 June 2021. https://culanth.org/fieldsights/the-photographed-giftparticipation-relief-efforts-and-social-media.

Shakya, Mallika. 2015. "The Question of Locality in Rupture. Hot Spots," Fieldsights, 14 October. https:// culanth.org/fieldsights/the-question-of-locality-inrupture

Sherpa, Pasang Y. 2014. "Climate Change, Perceptions, and Social Heterogeneity in Pharak, Mount Everest Region of Nepal." Human Organization 73(2): 153-161.

Sibley, C. G., and J. Bulbulia. 2012. "Faith after an Earthquake: A Longitudinal Study of Religion and Perceived Health before and after the 2011 Christchurch New Zealand Earthquake." PloS One 7(12). doi: 10.1371/journal. pone.0049648

Solmsdorf, Nikolai. 2014. Treasure-Traditions of Western Tibet: Rig-'dzin Gar-dbang rdo-rje snying-po (1640-1685) and His Activities in Mang-yul Gung-thang. München: Indus Verlag.

Sørensen, B. R., and K. Albris. 2016. "The Social Life of Disasters: An Anthropological Approach.” In Disaster Research: Multidisciplinarity and International Perspectives, edited by. Rasmus Dahlberg, Olivier Rubin, and Morten Thanning Vendelø,, 66-81. London: Routledge.

Spoon, Jeremy, Drew Gerkey, Ram B. Chhetri, Alisa Rai, Umesh Basnet, and Chelsea E. Hunter. 2021. "Understanding Short-term Household Recoveries from the 2015 Nepal Earthquakes: Lessons Learned and Recommendations." Progress in Disaster Science 10:100169.

Spoon, Jeremy, Chelsea E. Hunter, Drew Gerkey, Ram B. Chhetri, Alisa Rai, Umesh Basnet, and Anudeep Dewan. 2020. "Anatomy of Disaster Recoveries: Tangible and Intangible Short-term Recovery Dynamics Following the 2015 Nepal Earthquakes." International Journal of Disaster Risk Reduction 51:101879.

Stirrat, Jock. 2006. "Competitive Humanitarianism: Relief and the Tsunami in Sri Lanka." Anthropology Today 22(5): 11-15.

Tashi, Palden, and Kevin Stuart. 1998. "Perilous Novelties: The A-mdo Tibetan klu-rol Festival in Gling-rgyal Village." Anthropos 93: 31-53.

Thomas, F. W. 1957. Ancient Folk-Literature from Northeastern Tibet. Berlin: Akademie Verlag.

Warner, Cameron David, Heather Hindman, and Amanda Snellinger, eds. 2015. "Aftershocked: Reflections on the 2015 Earthquakes in Nepal.” Hot Spots series, Fieldsights, 14 October. https://preview.culanth.org/fieldsights/series/ aftershocked-reflections-on-the-2015-earthquakes-innepal

Yeh, Emily T., and Gaerrang. 2020. "Pests, Keystone Species, and Hungry Ghosts: the Gesar Epic and Human-Pika Relations." Cultural Geographies 1-18. DOI: 10.1177/1474474020963144

\section{Tibetan Sources}

'Bras ljongs lam yig. Gnas 'bras 'jongs (ljongs) gi (kyi) lam yig. Nepal-German Manuscript Preservation Project. Running No. L3358, Reel No. L278/8. Attributed to Padmasambhava, discovered by Rigzen Gödem at Chang Zangzang Lhadrag.

Ga'u bdun. 'Gu ru'i ga'u bdun ma. Attributed to Padmasambhava, discovered by Rigzen Gödem. Delhi: Dorjee Tsering.

Orgyan lung bstan. Orgyan chen po'i ma 'ongs lung bstan gar dbang rdo rje dang bya btang gro lod gnyis kyi gter nas spyan drangs pa. Part of collection, o rgyan chen po'i ma 'ongs lung bstan dang gang zag sgos kyi lung bstan nyi zla’i rgya 
can/ Select terma texts on Padmasambhava prophecies. See https://www.tbrc.org/\#!rid=W1KG9310

Padma gling pa lung bstan. Padma gling pa'i gter byon ma 'ongs lung bstan kun gsal me long zhe bya ba. Attributed to Padmasambhava, discovered by Pemalingpa at Bumtang Tarbaling.

Padma tshal gnas yig. Sbas yul padma'i tshal gyi gnas yig kun tu gsal ba'i me long. Attributed to Padmasambhava, discovered by Tsetan Gyaltsen at Mon Chumo Cave. In Collected Biographies and Prophesies of the Byang-gter Tradition, 507-513. Gangtok: Sherab Gyaltsen and Lama Dawa.
Skyid mo lung lam yig. Sbas yul skyid mo lung gi lam yig gags sel. Attributed to Padmasambhava, discovered by Rigzen Gödem in 1366 at Chang Zangzang Lhadrag. In Collected Biographies and Prophesies of the Byang-gter Tradition, 557-598. Gangtok: Sherab Gyaltsen and Lama Dawa.

Yol mo gnad byang. Yol mo gangs ra'i gnad byang. Attributed to Padmasambhava, discovered by Rigzen Gödem. In Collected Biographies and Prophesies of the Byang-gter Tradition, 529-536. Gangtok: Sherab Gyaltsen and Lama Dawa, 1983. 